\title{
The maintenance record of the KSTAR helium refrigeration system
}

\author{
K.-M. Moon*, J.-J. Joo, N.-W. Kim, Y.-B. Chang, D.-S. Park, S.-W. Kwag, N.-H. Song, H.-J. Lee, Y.-J. Lee, Y.-M. Park, \\ H.-L. Yang, and Y.-K. Oh
}

National Fusion Research Institute, Daejeon, Korea

(Received 22 November 2013; revised or reviewed 18 December 2013; accepted 19 December 2013)

\begin{abstract}
Korea Superconducting Tokamak Advanced Research (KSTAR) has a helium refrigeration system (HRS) with the cooling capacity of $9 \mathrm{~kW}$ at $4.5 \mathrm{~K}$. Main cold components are composed of 300 tons of superconducting (SC) magnets, main cryostat thermal shields, and SC current feeder system. The HRS comprises six gas storage tanks, a liquid nitrogen tank, the room temperature compression sector, the cold box $(\mathrm{C} / \mathrm{B})$, the 1st stage helium distribution box (DB\#1), the PLC base local control system interconnected to central control tower and so on. Between HRS and cold components, there's another distribution box (DB\#2) nearby the KSTAR device. The entire KSTAR device was constructed in 2007 and has been operated since 2008. This paper will present the maintenance result of the KSTAR HRS during the campaign and discuss the operation record and maintenance history of the KSTAR HRS.
\end{abstract}

Keywords : KSTAR (Korea Superconducting Tokamak Advanced Research), HRS (Helium Refrigeration System), MTBM (Mean Time Between Maintenance), MTBF (Mean Time Between Failure), System Reliability, CRMs(cryogenic rotating machines), CC(Cold compressor)

\section{INTRODUCTION}

The KSTAR HRS consists of various components, such as rotating machines, valves, pumps, sensors and instruments, they are required not only preventive maintenances but also failure maintenance for the proper operation of the HRS.

The main components of the KSTAR HRS can be divided into the following major equipment [1]: (i) The warm compression system (WCS) is composed of the compressors station $(\mathrm{C} / \mathrm{S})$ and the oil removal system (ORS), (ii) the cold box $(\mathrm{C} / \mathrm{B})$, (iii) the distribution box (D/B), (iv) the gas management system (GMS). Fig. 1 shows the system layout of the KSTAR HRS.

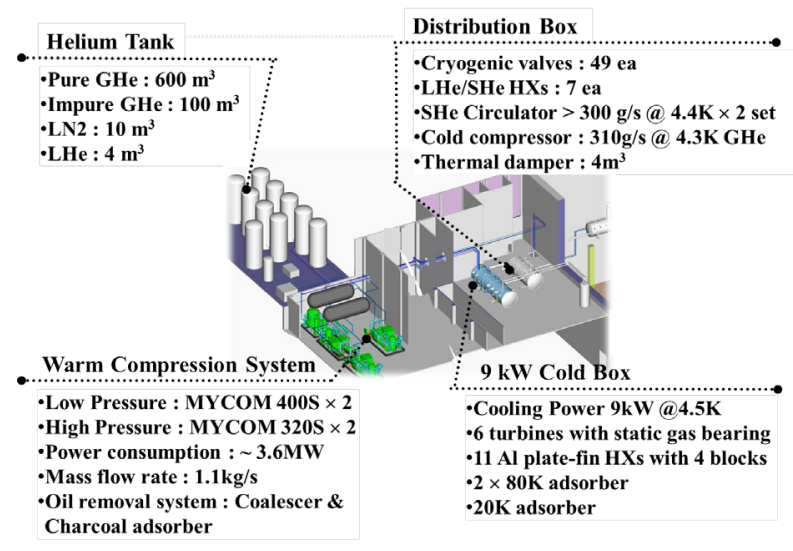

Fig. 1. System layout of the KSTAR HRS.

\footnotetext{
* Corresponding author: kmmoon@nfri.re.kr
}

\section{MAINTENANCE AND REPAIR RECORD OF THE KSTAR HRS}

There are lots of rotating and actuating components in the KSTAR HRS, it is important to manage the components in normal. The maintenance of actuating components should be performed as per the operation time and Table 1 shows the operation time of the major components of the KSTAR HRS. According to Table 1, the longest operated system is the motor \& compressor and it has been operated more than 21,000 hours, in contrast the cold compressor was the shortest operated machine whose operation time was less than 10,000 hours.

TABLE I

OPERATION TIME OF MAJOR ROTATING MACHINES IN THE KSTAR GRS.

\begin{tabular}{c|c|c|c|c}
\hline \multirow{2}{*}{ Items } & \multicolumn{2}{|c|}{$\begin{array}{c}\text { Operation time } \\
(\mathrm{hr})\end{array}$} & \multicolumn{2}{c}{$\begin{array}{c}\text { Total } \\
(\mathrm{hr})\end{array}$} \\
\cline { 2 - 5 } & ${ }^{\prime} 07 \sim 99$ & ${ }^{\prime} 10 \sim ' 13$ & $\begin{array}{c}\text { Sub } \\
\text { Total }\end{array}$ & $\begin{array}{c}\text { Grand } \\
\text { Total }\end{array}$ \\
\hline Motors & 9,264 & 12,033 & $16,065(5,232)$ & 21,297 \\
\hline Compressors & 9,264 & 12,033 & $19,365(1,932)$ & 21,297 \\
\hline Turbine \#1 & 5,280 & 10,992 & - & 16,272 \\
\hline Turbine \#2 & 5,280 & 10,992 & $11,689(4,583)$ & 16,272 \\
\hline Turbine \#3 & 5,256 & 11,091 & $5,256(11,091)$ & 16,347 \\
\hline Turbine \#4 & 4,416 & 8,966 & - & 13,382 \\
\hline Turbine \#5 & 4,296 & 8,877 & - & 13,173 \\
\hline Turbine \#6 & 3,648 & 8,181 & - & 11,829 \\
\hline TF circulator & 3,504 & 7,803 & $5,592(5,715)$ & 11,307 \\
\hline PF circulator & 3,463 & 7,690 & $10,163(990)$ & 11,153 \\
\hline $\begin{array}{c}\text { Cold } \\
\text { compressor }\end{array}$ & 3,486 & 6,722 & $4,446(5,762)$ & 10,208 \\
\hline $\begin{array}{c}\text { Vacuum } \\
\text { pumps }\end{array}$ & 9,264 & 12,011 & $19,338(1,937)$ & 21,275 \\
\hline \multicolumn{3}{|c}{$*()$ Operation time after maintenance } \\
\hline
\end{tabular}


To keep the best condition of the rotating machine, it is necessary to perform the preventive maintenance of the machines in time and the MTBM of each machine is indicated in the HRS operation manual [2].

\subsection{Warm Compressor system (Motor \& Compressor)}

The helium compressors and motors are required periodic maintenance because they should be operated continuously since the $1^{\text {st }}$ operation of KSTAR in 2008. According to the maintenance manual, the MTBM of the helium compressors is 35,000 hours and the MTBM of motors is 20,000 hours. Even though the operation time of the helium compressors and motors didn't reached MTBM, but the preventive maintenance was performed in 2011 for electrical motor and in 2012 for helium compressors because the WCS had been operated under the high vibration condition. The maintenance procedure of the electric motors for the helium compressors is shown in Fig. 2 The major maintenance items are bearing inspection and replacement, reinforcement of the stator winding, correction of the rotor unbalance and running test. Maintenance result is shown in Table 2 and after the maintenance of the electric motors, the insulation resistances had been increased about more than $30,000 \mathrm{M} \Omega$ and residual unbalances had been dropped to less than about 3 gram.

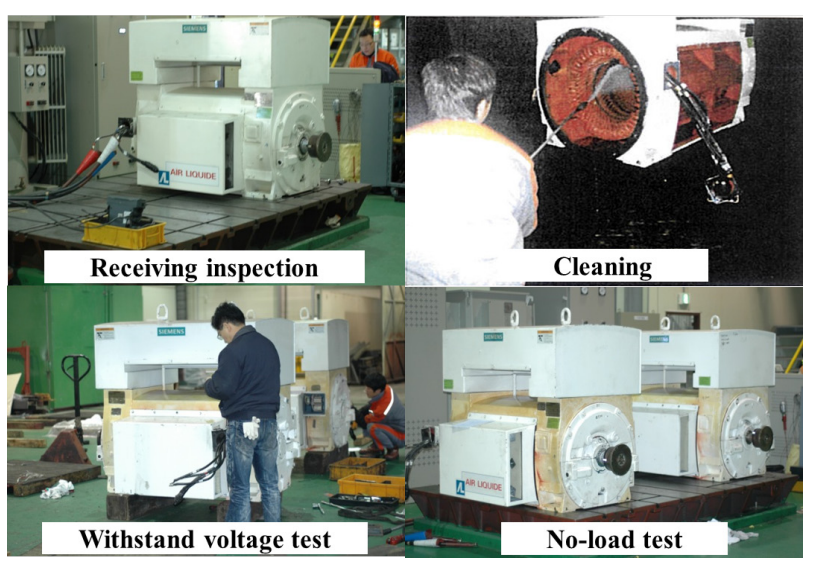

Fig. 2. Maintenance procedure of the motor.

TABLE II

MAINTENANCE RESULT OF THE MOTOR.

\begin{tabular}{c|c|c|c|c|c|c}
\hline \multirow{2}{*}{ Item } & \multicolumn{3}{|c|}{ Electric resistance } & \multicolumn{2}{c}{$\begin{array}{c}\text { Mechanical } \\
\text { properties }\end{array}$} \\
\cline { 2 - 7 } & \multicolumn{2}{|c|}{\begin{tabular}{c} 
Winding \\
\cline { 2 - 7 }
\end{tabular}} & \multicolumn{2}{|c}{$\begin{array}{c}\text { insulation } \\
1,000 \mathrm{M} \Omega\end{array}$} & \multicolumn{2}{c}{$\begin{array}{c}\text { Balancing } \\
3.5 \mathrm{~g} \downarrow\end{array}$} \\
\cline { 2 - 7 } & before & after & before & after & before & after \\
\hline LP 100 & 1.35 & 1.28 & 6,500 & 47,000 & 24 & 0.9 \\
\hline LP 200 & 1.35 & 1.28 & 8,500 & 67,500 & 17 & 1.17 \\
\hline HP400 & 0.74 & 0.73 & 8,800 & 33,400 & 34 & 0.78 \\
\hline HP 500 & 0.74 & 0.72 & 8,900 & 35,200 & 4 & 0.66 \\
\hline
\end{tabular}

Since the helium compressors are the basest components of KSTAR HRS, when the helium compressors were damaged the whole HRS goes to emergency shut-down (ESD). The forecasted job of the compressor maintenance is replacement of bearings and shaft seal. The procedure of the compressor maintenance is shown in Fig. 3.

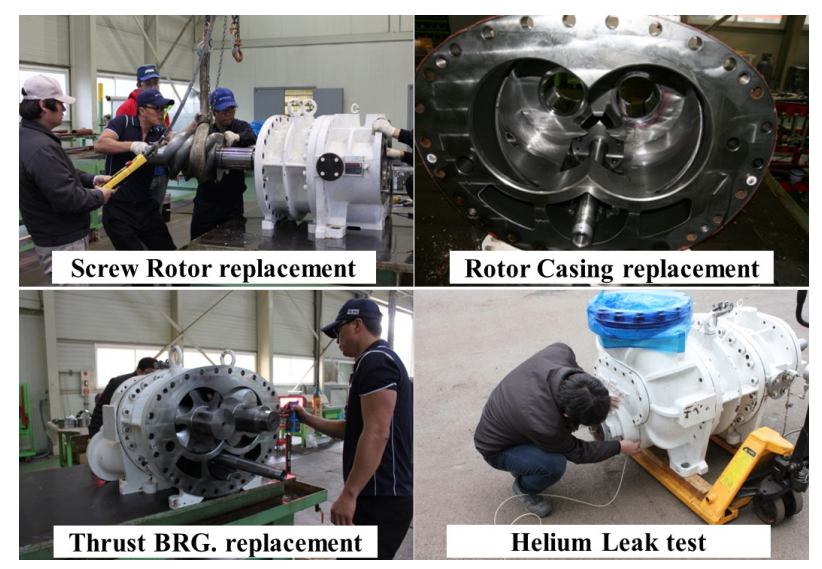

Fig. 3. Maintenance procedure of the compressor..

TABLE III

INSPECTION RESULTS OF THE LP HELIUM COMPRESSORS.

\begin{tabular}{|c|c|c|}
\hline \multicolumn{3}{|c|}{ Low Pressure Compressor } \\
\hline Items & LP Comp.(C100) & LP Comp.(C200) \\
\hline Male Rotor & $\begin{array}{l}\text { Deep scratch on the tip } \\
\text { \&lobe(replacement) }\end{array}$ & $\begin{array}{l}\text { Deep scratch on the } \\
\text { tip(replacement) }\end{array}$ \\
\hline Female Rotor & $\begin{array}{l}\text { Deep scratch on the tip } \\
\text { \&lobe (replacement) }\end{array}$ & $\begin{array}{l}\text { Deep scratch on the tip } \\
\text { (replacement) }\end{array}$ \\
\hline Shaft Seal & Normal wear & Normal wear \\
\hline Balance Piston & Deep wear & Normal wear \\
\hline Slide Valve & Deep scratch & No damage \\
\hline Rotor Casing & $\begin{array}{l}\text { Deep scratch on the } \\
\text { Male \&Female } \\
\text { housing(replacement) }\end{array}$ & $\begin{array}{l}\text { Deep scratch on the Male } \\
\text { \&Female housing } \\
\text { (replacement) }\end{array}$ \\
\hline Journal BRG. & $\begin{array}{l}\text { Normal wear } \\
\text { (replacement) }\end{array}$ & $\begin{array}{l}\text { Normal wear } \\
\text { (replacement) }\end{array}$ \\
\hline Thrust BRG. & $\begin{array}{l}\text { No damage } \\
\text { (replacement) }\end{array}$ & $\begin{array}{l}\text { No damage } \\
\text { (replacement) }\end{array}$ \\
\hline Unloader parts & No damage & No damage \\
\hline \multicolumn{3}{|c|}{ High Pressure Compressor } \\
\hline Items & HP Comp.(400) & HP Comp.(C500) \\
\hline Male Rotor & Normal wear on the tip & Normal wear on the tip \\
\hline Female Rotor & Normal wear on the tip & Normal wear on the tip \\
\hline Shaft Seal & $\begin{array}{l}\text { Abnormal wear on the } \\
\text { carbon }\end{array}$ & $\begin{array}{l}\text { Abnormal wear on the } \\
\text { carbon }\end{array}$ \\
\hline Balance Piston & Normal wear & Normal wear \\
\hline Slide Valve & No damage & No damage \\
\hline Rotor Casing & No damage & No damage \\
\hline Journal BRG. & $\begin{array}{l}\text { Normal wear } \\
\text { (replacement) }\end{array}$ & $\begin{array}{l}\text { Normal wear on the male } \\
\text { side BRG. (replacement) }\end{array}$ \\
\hline Thrust BRG. & $\begin{array}{l}\text { No damage } \\
\text { (replacement) }\end{array}$ & $\begin{array}{l}\text { No damage } \\
\text { (replacement) }\end{array}$ \\
\hline Unloader parts & No damage & $\begin{array}{l}\text { Light scratch on the } \\
\text { Unloader piston housing }\end{array}$ \\
\hline
\end{tabular}


Unfortunately, serious damage of the low pressure compressor was found during the inspection and the major parts of compressor such as screw rotor set, casings and unloader piston should be replaced. The high pressure compressor didn't have any damage at major part and it could be performed the maintenance in normal. The replacement of the major parts for low pressure compressors spent a lot of time and it delayed the KSTAR campaign in 2013 for 4 months. The inspection result of the elium compressors for the KSTAR HRS is shown in Table 3

\subsection{Cryogenic rotating machines (CRMs)}

The CRMs of the KSTAR HRS, such as the supercritical helium (SHe) circulator and the cold compressor (CC) to be inspected regularly and the major overhaul is required essentially when the MTBM occurs. According to the maintenance schedule [2], the MTBM of the CRMs of the KSTAR HRS was 10,000 hours.

But, the CC was a failure at the early of plasma operation period in 2010 with the high vibration value and the Poloidal Field circulator (PF circulator) was tripped at the end of the $3^{\text {rd }}$ campaign of KSTAR in 2010. The operating time of PF circulator was 5,533 hours after initial installation and that of the $\mathrm{CC}$ was 960 hours from previous repair in 2010. The $\mathrm{CC}$ and the $\mathrm{SHe}$ circulators were delivered and repaired at the manufacturer's shop during the KSTAR maintenance period.

According to manufacturer's repair report, the ball bearings of the $\mathrm{CC}$ were broken and the grease was dried out. It is supposed that the grease dry-out occurred due to the badness of lubrication in the bearing and it made the failure of the $\mathrm{CC}$. It is doubt that the grease dry-out was the major problem of the $\mathrm{CC}$ failure. The bearing replacement job was performed and the counter plan of grease dry-out was established at the installation procedure for the CC. Fig. 4 shows The visual inspection result of $\mathrm{CC}$ bearing.

Fig. 5 (a) show the status of inner component of the Toroidal Field circulator (TF circulator). In case of the TF circulator, no damage and abnormal weak were found. But, severe wear and surface damage on the bearing parts of the PF circulator were observed as shown in Fig. 5 (b).

It is supposed that the difference between the TF circulator and the PF circulator are from operation condition. As shown in Fig. 6, the pressure rising and change of the PF circuit is larger than that of the TF circuit and they effect dynamic gas bearing of the PF circulator. To cope with large pressure load on the PF circulator, the optimized operation scenario of the PF magnets is developing and the strong bearing design of the PF circulator is under consideration simultaneously [4].
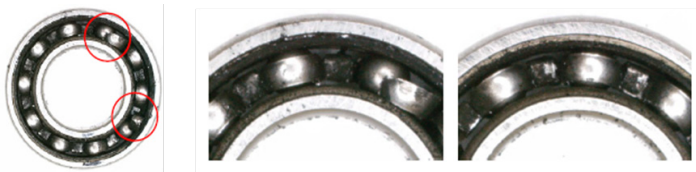

(A) marked side

(B) unmarked side

Fig. 4. Visual inspection of CC bearing interior.

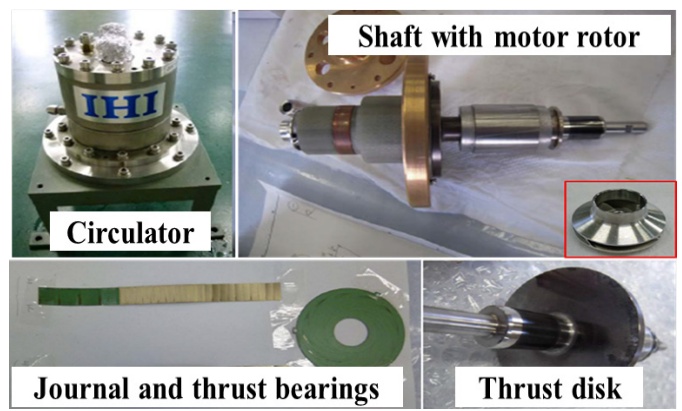

(a) TF Circulator.

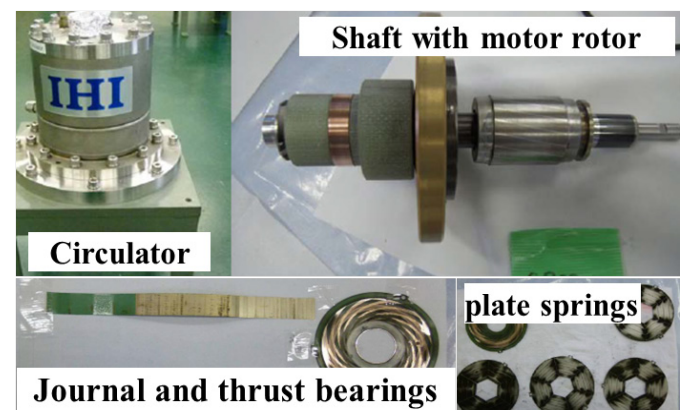

(b) PF Circulator.

Fig. 5. Visual inspection result of the SHe circulators.

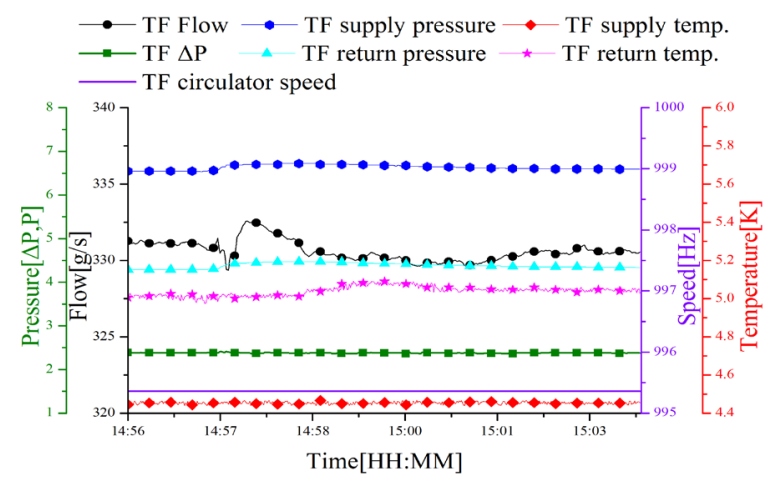

(a) TF Circulator trend.

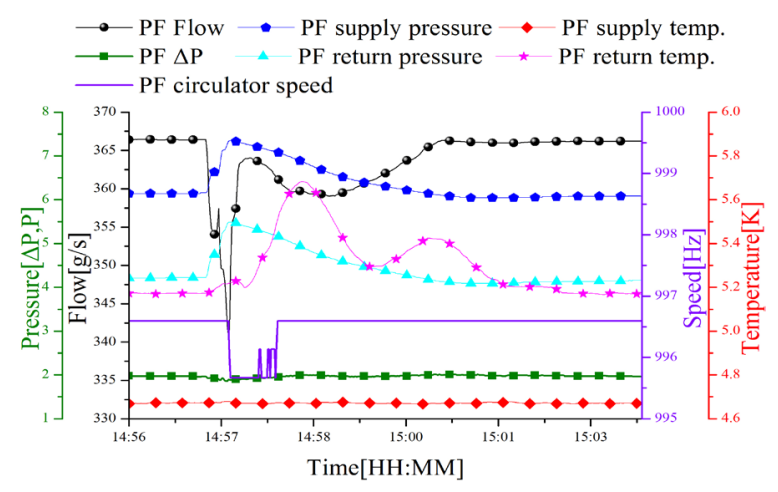

(b) PF Circulator trend.

Fig. 6. Typical operation trend of the TF, PF circulator during the KSTAR shot. 
After the repair job was completed, the installation and commissioning job was carried out at the NFRI site. The CC was installed according to modified conditioning job to avoid the grease dry-out. The $\mathrm{SHe}$ circulators were installed as per the manufacturer's procedure also. After the installation the running test at the room temperature was performed and the performance test at the cryogenic temperature had been carried out.

\section{RELIABILITY ANALYSIS}

During the KSTAR campaign, total 22 abnormal events had occurred on the KSTAR HRS and Table 4 shows that and their consequences since 2008 .

The most severe event was oil pump failure and it made whole system stop. The oil pump had been tripped 4 times due to the bearings failure until 2010. The oil pump manufacturer changed bearing specification to avoid the repetitive failure in 2010, unfortunately it happened twice in 2011. The oil pump had been failed total 6 times even if the bearing specification was changed. The root cause and engineering solution have not been evaluated yet and is still being in progress without manufacturer's technical support.

The electric power failure so called "Blackout" should not be happened but it is not controllable. Most of blackout did not influence on the HRS operation because it occurred in very short time $(<0.5 \mathrm{~s})$. But when the duration of blackout is longer than $0.5 \mathrm{~s}$ or the voltage drop is larger than $20 \%$, the ESD of the KSTAR HRS is unavoidable.

According to our experience, it is necessary for $\sim 60$ hours for the recovery from the ESD at $4.5 \mathrm{~K}$.

TABLE IV

CASES OF ABNORMAL EVENTS AND ITS CONSEQUENCES.

\begin{tabular}{l|c|l}
\hline \multicolumn{1}{c|}{ Event } & $\begin{array}{c}\text { Count } \\
(\%)\end{array}$ & \multicolumn{1}{|c}{ Consequences } \\
\hline Oil pump failure & $6(27 \%)$ & $\begin{array}{l}\text { When none of redundant pump } \rightarrow \\
\text { HRS ESD }\end{array}$ \\
\hline Black out & $7(32 \%)$ & HRS emergency shut-down(ESD) \\
\hline Turbine broken & $1(5 \%)$ & Cool-down delayed \\
\hline Valve relay failure & $2(9 \%)$ & All valves closed \\
\hline $\begin{array}{l}\text { Cold compressor } \\
\text { failure }\end{array}$ & $2(9 \%)$ & $\begin{array}{l}\text { Temperature of the TD was } \\
\text { increased }(0.14 \mathrm{~K} \uparrow)\end{array}$ \\
\hline SHe circulator trip & $4(18 \%)$ & $\begin{array}{l}\text { SHe supply reduced from } 300 \mathrm{~g} / \mathrm{s} \text { to } \\
100 \mathrm{~g} / \mathrm{s}\end{array}$ \\
\hline \multicolumn{1}{c}{ Total } & $\mathbf{2 2 ( 1 0 0 \% )}$ & \\
\hline
\end{tabular}

TABLE V

SYSTEM AVAILABILITY OF THE KSTAR HRS SINCE 2008.

\begin{tabular}{c|c|c|c}
\hline Year & $\begin{array}{c}\text { Campaign } \\
\text { period }\end{array}$ & $\begin{array}{c}\text { Suspension } \\
\text { period }\end{array}$ & Availability \\
\hline 2008 & $2,976 \mathrm{hr}$ & $61 \mathrm{hr}$ & $98.0 \%$ \\
\hline 2009 & $2,472 \mathrm{hr}$ & $261 \mathrm{hr}$ & $89.4 \%$ \\
\hline 2010 & $4,104 \mathrm{hr}$ & $502 \mathrm{hr}$ & $87.8 \%$ \\
\hline 2011 & $3,144 \mathrm{hr}$ & $122 \mathrm{hr}$ & $96.1 \%$ \\
\hline 2012 & $3,120 \mathrm{hr}$ & $110 \mathrm{hr}$ & $96.5 \%$ \\
\hline 2013 & $1,800 \mathrm{hr}$ & $0 \mathrm{hr}$ & $100 \%$ \\
\hline Total & $15,816 \mathrm{hr}$ & $1,056 \mathrm{hr}$ & $93.3 \%$ \\
\hline
\end{tabular}

Generally, the system reliability can be expressed as the ratio between the actual operation time and total operation so called "availability." Table 5 shows the availability of the KSTAR HRS during the KSTAR campaign.

\section{SUMMARY}

The KSTAR HRS showed $9.5 \mathrm{~kW}$ at $4.5 \mathrm{~K}$ during the commissioning period and has supported the KSTAR plasma operation properly.

As an experience of the KSTAR HRS operation for 6-years, the failures of the major live component and utility failure increase the system suspension time and it decreases the system reliability. Unfortunately, the MTBF and MTBM in the technical document of the equipment was not consistent for the components failure and the maintenance but it was only available as a reference. The average availability of the KSTAR HRS since 2008 is $93.3 \%$. Annual availability is going better but it is not sufficient for ordinary plant standard.

To improve the system availability, the reliability analysis of major equipment is being investigated and the enhancement plan of the system reliability should be adopted.

\section{ACKNOWLEDGEMENT}

This study is supported by the Ministry of Science, ICT and Future Planning under the KSTAR project.

\section{REFERENCES}

[1] Fauve, E. et. al.: Design, construction and performances of the KSTAR Helium Refrigeration System. Proc. of ICEC22-ICMC2008, 637-642, 2008.

[2] Beauvisage, J. et. al.: HRS Maintenance Manual. Helium Refrigeration System of the KSTAR Project C1119-PO-111 (0), 2008.

[3] Joo, J.-J. et. al.: Maintenance Result of the WCS Motors. Internal Report of the National Fusion Research Institute, 2013.

[4] Chang, y.-b. et. al.: Maintenance Result of IHI SHe Circulator \& Cold Compressor. Internal Report of the National Fusion Research Institute, 2012. 